Schulich School of Law, Dalhousie University

Schulich Law Scholars

Research Papers, Working Papers, Conference

Papers

Faculty Scholarship

8-25-2012

\title{
The Law Applicable on the Continental Shelf and in the Exclusive Economic Zone
}

Moira McConnell

Dalhousie University, moira.mcconnell@dal.ca

Follow this and additional works at: https://digitalcommons.schulichlaw.dal.ca/working_papers

\section{Recommended Citation}

McConnell, Moira, "The Law Applicable on the Continental Shelf and in the Exclusive Economic Zone" (2012). Research Papers, Working Papers, Conference Papers. 40.

https://digitalcommons.schulichlaw.dal.ca/working_papers/40

This Working Paper is brought to you for free and open access by the Faculty Scholarship at Schulich Law Scholars. It has been accepted for inclusion in Research Papers, Working Papers, Conference Papers by an authorized administrator of Schulich Law Scholars. For more information, please contact hannah.steeves@dal.ca. 


\title{
The Law Applicable on the Continental Shelf and in the Exclusive Economic Zone ${ }^{1}$
}

\author{
Moira L. McConnell
}

\subsection{Introduction}

As an initial observation, I note that this topic presents a challenge for comparative law scholars. ${ }^{2}$ As one scholar suggested in correspondence about the questionnaire for this Session, the topic is, arguably, simply a question of implementation of public international law rather than domestic (and comparative) law as such. This view points to a problem of disciplinary boundaries and the potential overlap between comparative law and international $\operatorname{law}^{3}$ and the emerging regional

${ }^{1}$ II.D., Le droit applicable sur le plateau continental et dans la zone économique exclusive.

${ }^{2}$ National reports were submitted by the following: Belgium (Eduard (Eddy) Somers, Frank Maes); Canada (Denis Roy); Germany (Wolfgang Wurmnest); Italy (Tullio Treves, Irini Papanicolopulu); Japan (Souichirou Kozuka, Hideyuki Nakamura); Netherlands (Christiaan P. Verwer); Norway (Tore Henriksen); Peru (José Antonio Saavedra Calderón, Angel Horna); Poland (Maria Dragun-Gertner, Dorota Pyć, Zuzanna Peplowska); Portugal (Luís de Lima Pinheiro); Slovenia (Petra Ferk); USA (Rachael E. Salcido), and Venezuela (Angelina Jaffé). This General Report benefited from comments at the Session from the reporters for Poland, Belgium, Japan, USA, and Portugal and from the Chair, Dr. Jürgen Basedow.

${ }^{3}$ See, for example, the International and Comparative Law Quarterly (Cambridge University Press/British Institute of International and Comparative Law) or even more recently, a journal Transnational Legal Theory (Hart Publishing, Oxford) $<\mathrm{http}: / /$ www.hartjournals.co.uk/tlt/index.html >. It was interesting to see that this issue was also the subject of debate at the opening plenary of the 18th Congress on "The Role of Comparative Law in Courts and International Tribunals" and

M.L. McConnell ( $\varangle)$

Schulich School of Law, Marine \& Environmental

Law Institute, Dalhousie University, Halifax, NS, Canada

e-mail: moira.mcconnell@dal.ca law scholarship. ${ }^{4}$ I mention this at the beginning of my General Report because that tension is apparent in both the National Reports ${ }^{5}$ and the questionnaire prepared for this Session. Are we simply looking at the question of jurisdictional claims and national implementation of the law of the sea, as codified in the 1982 United Nations Convention on Law of the Sea ${ }^{6}$ (LOSC) or the predecessor 1958 Conventions $^{7}$ and/or customary international law for countries that have not ratified the 1982 Convention? $^{8}$ If this is the case, particularly in the context of codification and the inevitable tendency to uniformity under the LOSC, is this Session concerned only with descriptive reports of spatial claims and the extent of implementation of these public

at the Session on "International Law in Domestic Systems". As Craig Scott, the Convening Editor, notes in "Introducing Transnational Legal Theory" in Volume 1, March 2010:

Transnational Legal Theory's mandate includes theoretical work that explores fresh (or revived) understandings of both international law and comparative law 'beyond the state' (and the interstate). In particular, we seek works that explore the interfaces, intersections and mutual embeddedness of public international law, private international law and comparative law, in terms of whether and how such inter-relationships are reshaping and blending these sub-disciplines in directions that are in important respects 'transnational' in nature.

${ }^{4}$ Especially in the European Union (EU) context.

${ }^{5}$ See, for example, the National Report by Dr. Wurmnest (Germany).

${ }^{6}$ ILM 1261 (1982). Online: <http://www. un.org/depts./los>.

${ }^{7}$ Convention on the Continental Shelf, 29 April 1958, 499

U.N.T.S. 311; Convention on the High Seas, 29 April 1958, 450 U.N.T.S. 82.

${ }^{8}$ See the National Reports by Professor Salcido (United States of America (USA)) and Professor Jaffé (Venezuela). 
international law obligations and rights as "the law" applicable to these areas?

Certainly, recent events such as the environmental disaster and the loss of life from the accident in the offshore oil exploitation in the Gulf of Mexico ${ }^{9}$ and, before that, the shipping-related spills near the coasts of Europe ${ }^{10}$ or Australia ${ }^{11}$ and elsewhere ${ }^{12}$ have generated significant interest in questions such as who regulates? to what standards? and, ultimately, who has responsibility and liability for activities in these wider ocean areas near coastlines? In fact these incidents, as well as the development of technology to allow for more activities in and near coastal waters, have been the catalyst for the developments in the law of the sea and the related international regulatory regime under the auspices of the International Maritime Organization (IMO), largely because activities such as shipping are often inherently transnational or global in their operations and not only cross jurisdictions but are also a point where multiple jurisdictions intersect. Despite an increasingly elaborate and articulated regime at the international level there are, however, some areas of tension. The resulting challenges to the international regime arise from national responses to such incidents, particularly in connection with the question of navigational rights of foreign flag ships navigating through the Territorial Sea and Exclusive Economic Zone (EEZ) of another State. ${ }^{13}$

\footnotetext{
${ }^{9}$ For example, at the end of April 2010, the "Deep Water Horizon" deep sea offshore oil drilling unit spill/leak in the Gulf of Mexico that involved the death of a number of rig workers and that is having a major impact on the coast of the USA, as well as resulting in multiple investigations and a burgeoning number of law suits and other claims. As noted by Professor Salcido (USA) in her comments to the Congress Session, crisis often drives the development of law and reforms.

${ }^{10}$ In 2002, the Prestige sought and was denied a place of refuge. Ultimately it sank and began to leak oil approximately $250 \mathrm{~km}$ off Spain and polluted much of the coastline.

${ }^{11}$ On 5 April 2010, the grounding of the coal carrier Shen Neng 1 caused a fuel oil and possible coal spill on the Great Barrier Reef.

${ }^{12}$ The early-1990s oil spill from the Exxon Valdez in Alaskan waters promoted the push in IMO to "double hull" tankers. The Amoco Cadiz incident in 1976 near the coast of France is often heralded as the turning point with respect to MARPOL 73/78 and related instruments.

${ }^{13}$ See, for example, the reference to the European Court of Justice regarding the validity of an EC Directive 2005/35 on ship-source pollution and penalties for infringements and its decision in Case 308/06: The Queen on the application of
}

However disturbing and interesting these high profile events and their potential impact on the international legal regime is, the focus and concerns of this General Report are somewhat different. The questionnaire prepared for this Session reflected the view that the topic, "the law applicable on the continental shelf and in the exclusive economic zone," provides an opportunity to engage in a broad consideration, on a comparative basis, of the extent and nature of coastal States' juridical "occupation" of the extended areas of ocean and submerged land (i.e., the continental shelf). It suggested that this field of study might consider, and indeed it is difficult to avoid, the implications for the international regime and questions of implementation of conventional law or the development of customary law. However, it should also include an examination of the extent to which coastal States have "occupied" this new spatial frontier in their domestic law in the various spheres of concern. Of course this consideration must necessarily be viewed against the backdrop of the unique legal nature of these extended spaces and the troubling problem of articulating the basis of claims to jurisdiction, particularly in connection with the EEZ. At the same time the inquiry should heed the caution voiced by Bernard Oxman in his 2006 essay "The Territorial Temptation: A Siren Song at Sea" ${ }^{14}$ where he argues that:

... in fact the law of the land and the law of the sea developed in very different ways. If the history of the international law of the land can be characterized by

INTERTANKO, INTERCARGO, The Greek Shipping Cooperation Committee, Lloyd's Register, The International Salvage Union v. The Secretary of State for Transport. Judgment. At <http://eur-lex. europa.eu> Court of Justice of the European Communities (Grand Chamber), June 3, 2008. The Court was asked to consider the following questions:

- Whether the EU can impose criminal liability for discharges from foreign-flag ships on the high seas or in the Exclusive Economic Zone independently of MARPOL, thereby limiting MARPOL defences;

- Whether the standard of criminal liability for discharges resulting from "serious negligence" breaches the right of Innocent passage";

- Whether the EU can legislate for discharges in territorial seas otherwise than in accordance with MARPOL, again limiting MARPOL defences and expanding parties who might be liable;

- Whether the standard of liability in the European Union directive of "serious negligence" satisfies the requirement of legal certainty.

${ }^{14}$ Centennial Essays, 100 AJIL (2006), 830-51, at 830. 
the progressive triumph of the territorial temptation, the history of the international law of the sea can be characterized by the obverse; namely, the progressive triumph of Grotius's thesis of mare liberum and its concomitant prohibition on claims of territorial sovereignty....That triumph reflected not only the transitory nature of human activity at sea, but a rational conclusion that the interests of states in unrestricted access to the rest of the world outweighed their interests in restricting the access of others at sea.

This General Report, and the National Reports on which it is based, cannot, and do not, pretend to provide a definitive answer to the question implicitly posed in the title of the Session, as rhetorically posed by Dr. Wurmnest (Germany) - is this a "law free zone?" The answer in these National Reports is clear: it is not "law free". In fact, as Professor Dragun-Gertner (Poland) observed in her comments during the Session, the space for unique or diverse domestic legislation in the EEZ is, if anything, increasingly smaller because of the growth in overlapping international and regional regulatory regimes. ${ }^{15}$ However, the question of what is the applicable law and the basis for that law, particularly in connection with private law matters (e.g., contracts, property rights, torts), remains uncertain, and even undeveloped in many countries. The reasons for this vary but may include the fact that the range of activities in these areas still remains relatively narrow and primarily concerned with living and non-living resource exploitation and navigation. In addition the public nature of the space poses difficulties in some cases for developing individual legal rights. Thus there has been little need, and in indeed barriers, to develop the law. It may also be, as has been pointed out elsewhere that the "... classical manifestations of jurisdiction [territoriality, nationality and universality] are not followed in the law of the sea, where jurisdiction is attributed to States in their maritime context, i.e., either as flag States, coastal States and/or port States." ${ }^{16}$ While the law of the sea framework could

\footnotetext{
${ }^{15}$ She made this observation in connection with the interaction between the LOSC, IMO Conventions, the various UNEP and other UN Conventions, the Helsinki Convention (1992 Convention on the Protection of the Marine Environment of the Baltic Sea Area) and the various EU Directives.

${ }^{16}$ Erik Franckx, "Book review of Maria Gavouneli, Functional Jurisdiction in the Law of the Sea, Vol. 62, Publications on Ocean Development (Leiden: Martinus Nijhoff, 2007)," in Ocean Yearbook, vol. 23 eds. Coffen-Smout, S., Chircop, A., McConnell, M. (Leiden: Brill, 2009), 532. Of course these terms
}

also be understood as flowing from the "classical" basis it is also evident that the question of applicable law will depend on a range of factors.

The topic of this Session has preoccupied many scholars and formed the basis of nearly as many books and careful surveys on the nature of the EEZ and the continental shelf and the allocation of rights and responsibilities in these spaces, including the important general review in 1989 by Barbara Kwiatkowsa, The 200 mile Exclusive Economic Zone in the New Law of the Sea,${ }^{17}$ and more recently Maria Gavouneli, Functional Jurisdiction in the Law of the Sea, ${ }^{18}$ or the more sector specific analysis such as that by Eric Jaap Molenaar, Coastal State Jurisdiction Over Vessel-Source Pollution, ${ }^{19}$ to name but a few.

This General Report and the related National Reports can only purport to offer a "snapshot" of the current situation in a limited number of countries and legal systems combined with observations on some common themes and difficulties. Before moving to consider these snapshots of the contemporary situation it is useful to briefly review the legal background to the EEZ and the continental shelf.

\subsection{Background: The EEZ and the Continental Shelf}

It will be recalled that the term and the concept of the "Exclusive Economic Zone", as a description of coastal State use and legislative and management rights (with responsibilities) within a spatial area out to 200 nautical miles (NM) from shore was adopted in 1982 under the LOSC. It will also be recalled that the earlier Conventions, which were adopted in 1958, the

are simply descriptions of particular kinds of interest and legal roles since most States that have a maritime interest assume all three roles to varying degrees. Interestingly, under the ILO's Maritime Labour Convention, 2006 (NIF but expected 2012/2013) an additional "maritime" interest, that of laboursupplying responsibilities, is emerging, particularly in connection with regulation of seafarer recruitment and placement services and social security protection.

${ }^{17}$ Dordrecht/Boston/London: Martinus Nijhoff Publishers: 1989.

${ }^{18}$ Maria Gavouneli, Functional Jurisdiction in the Law of the Sea, vol. 62, Publications on Ocean Development (Leiden: Martinus Nijhoff, 2007).

${ }^{19}$ International Law and Policy Series, vol. 51 (The Hague: Kluwer, 1998). 
water column beyond the Territorial Sea was considered as high seas ${ }^{20}$ while the continental shelf was considered as a prolongation of the coastal State's land.

The development of the legal concept of an extended area, described as a "zone" - which in its very nomenclature reflects the increasingly dominant "planning" approach to the treatment of spatial areas where there may be conflicting users and claims, ${ }^{21}$ was described by Satya N. Nandan ${ }^{22}$ as follows:

The concept of the exclusive economic zone is one of the most important pillars of the 1982 Convention on the Law of the Sea. The regime of the exclusive economic zone is perhaps the most complex and multifaceted in the whole Convention. The accommodation of diverse issues contributed substantially to the acceptance of the concept and to the Convention as a whole. The 1982 Convention on the Law of the Sea is often referred to as a package. The metaphor is derived from a decision made during the Third United Nations Conference on the Law of the Sea that the Convention would be adopted in toto, as a "package deal". No single issue would be adopted until all issues were settled. This decision provided an essential mechanism for reconciling the varied interests of the states participating in the Conference. If a state's interests in one issue were not fully satisfied, it could look at the

\footnotetext{
${ }^{20}$ Article 1, Convention on the High Seas, supra note 7.

${ }^{21}$ The term itself implies a more abstract notion, clearly a legal construct, differing from "territory". See: Moira L. McConnell, "Conflict Prevention and Management: Designing Effective Dispute Resolution Strategies for Aquaculture Siting and Operations," in Aquaculture Law and Policy: Towards Principled Access and Operations, ed. VanderZwaag, D., and Chao, G. (London/New York: Routledge Press, 2006), 171-206 and sources discussed therein at footnote 21.

${ }^{22}$ S. N. Nandan, "The Exclusive Economic Zone: A Historical Perspective," in Essays in Memory of Jean Carroz (Rome: FAO, 1987). Available at: <http://www.fao.org/docrep/s5280T/ s5280t0p.htm>. Jean Carroz is quoted in Nandan's paper as stating, in 1981, that:
}

Since the seventeenth century, when the development of seaborne trade and the emergence of powerful maritime nations led to a shift from the notion of closed seas claimed by a few countries to the concept of open seas, the two basic principles of the law of the sea have been that a narrow strip of coastal waters should be under the exclusive sovereignty of the coastal state and that the high seas beyond should be freely accessible to all. These principles were originally intended to satisfy and reconcile the requirements of national security with freedom of trade and navigation. But they were applied to all activities in both areas and ipso facto defined the legal framework within which fishing activities were carried on. At the Conference on the Law of the Sea, there was only limited support for maintaining the status quo... whole package and find other issues where its interests were more fully represented, thereby mitigating the effects of the first. Thus, the Convention became an elaborately-constructed document built on trade-offs, large and small. The larger package consists of: a twelvenautical-mile territorial sea; an exclusive economic zone of up to 200 nautical miles in which coastal states have preeminent economic rights and which obviates the need for a territorial sea of 200 nautical miles claimed by some states; extension of the continental shelf regime to the margin, with revenue-sharing obligations beyond the exclusive economic zone; a regime for transit passage through straits used for international navigation and for archipelagic sea-lanes passage; guaranteed access to and from the sea for land-locked states; a regime for the administration and development of the common heritage resources of the international sea-bed area; protection and preservation of the marine environment; and adequate mechanisms for settlement of disputes concerning the interpretation and application of the provisions of the Convention. Within this larger package are many smaller packages of which the exclusive economic zone is one of the most interesting examples. The provisions contained in articles 55 and 75 reflect an array of interests: the sovereign rights of coastal states to manage the zone in good faith; the regard for the economic interests of third states; regulation of certain activities in the zone, such as marine scientific research, protection and preservation of the marine environment, and the establishment and use of artificial islands, installations and structures; freedom of navigation and overflight; the freedom to lay submarine cables and pipelines; military and strategic uses of the zone; and the issue of residual rights in the zone. (emphasis added)

Article 55 to which Nandan refers is the first Article in Part V, Exclusive Economic Zone, of the LOSC. It provides:

Article 55

Specific legal regime of the exclusive economic zone

The exclusive economic zone is an area beyond and adjacent to the territorial sea, subject to the specific legal regime established in this Part, under which the rights and jurisdiction of the coastal State and the rights and freedoms of other States are governed by the relevant provisions of this Convention.

Articles 56-75 outline the various rights, jurisdiction, and responsibilities of the coastal State in this zone beyond its Territorial $\mathrm{Sea}^{23}$ (maximum of $12 \mathrm{NM}$ ) and deals with specific activities, primarily in

\footnotetext{
${ }^{23}$ Article 2 of LOSC extends coastal State sovereignty from land and internal waters out to an adjacent belt of sea, the territorial sea, and to the seabed and subsoil and airspace above it, to a maximum of 12 NM from a State's baselines.
} 
the water superjacent to the seabed and subsoil out to 200NM. Specifically, Article 56 provides that:

Rights, jurisdiction and duties of the coastal State in the exclusive economic zone

1. In the exclusive economic zone, the coastal State has:

(a) sovereign rights for the purpose of exploring and exploiting, conserving and managing the natural resources, whether living or non-living, of the waters superjacent to the seabed and of the seabed and its subsoil, and with regard to other activities for the economic exploitation and exploration of the zone, such as the production of energy from the water, currents and winds;

(b) jurisdiction as provided for in the relevant provisions of this Convention with regard to:

(i) the establishment and use of artificial islands, installations and structures;

(ii) marine scientific research;

(iii) the protection and preservation of the marine environment;

(c) other rights and duties provided for in this Convention.

2. In exercising its rights and performing its duties under this Convention in the exclusive economic zone, the coastal State shall have due regard to the rights and duties of other States and shall act in a manner compatible with the provisions of this Convention.

3. The rights set out in this article with respect to the seabed and subsoil shall be exercised in accordance with Part VI. (emphasis added)

Paragraph 3 references Part VI, Continental Shelf, and in so doing incorporates Articles 76-85, as applicable. Key amongst these is Article 77 which provides:

\section{Rights of the coastal State over the continental shelf}

1. The coastal State exercises over the continental shelf sovereign rights for the purpose of exploring it and exploiting its natural resources.

2. The rights referred to in paragraph 1 are exclusive in the sense that if the coastal State does not explore the continental shelf or exploit its natural resources, no one may undertake these activities without the express consent of the coastal State.

3. The rights of the coastal State over the continental shelf do not depend on occupation, effective or notional, or on any express proclamation.

4. The natural resources referred to in this Part consist of the mineral and other non-living resources of the seabed and subsoil together with living organisms belonging to sedentary species, that is to say, organisms which, at the harvestable stage, either are immobile on or under the seabed or are unable to move except in constant physical contact with the seabed or the subsoil. (emphasis added)

Article 81 further clarifies that the coastal State has the exclusive right to authorize and regulate drilling on the continental shelf for all purposes. Article 78 makes it clear, however, that these rights do not affect the legal status of the superjacent waters or airspace above the waters.

Both Parts V and VI also preserve certain pre-existing "high seas freedoms" that can be exercised by other States in the EEZ and on the continental shelf. Notably in the EEZ, Article 58, expressly references freedom of navigation and overflight and laying of submarine cables and pipes and incorporates other provisions from Part VII, High seas, in Articles 88-115 if not incompatible with Part V. A State operating (e.g., flag State with a ship navigating) in another State's EEZ is to comply with laws adopted under Article V and other applicable international law adopted by the coastal State. Similarly, in Part VI, Article 79 expressly preserves the right of other States to lay submarine cables and pipes on the continental shelf, subject to a right of the coastal State to regulate for specific purposes. It should be noted that under Article 60, coastal States have the exclusive right to construct and authorize the construction of artificial island installations and have exclusive jurisdiction over these with respect to customs, fiscal, health, safety, and immigration law and regulation. Article 73 sets out coastal States' rights regarding enforcement of law and regulation in the EEZ in connection with its "sovereign rights to explore, exploit, conserve and manage the living resources in the exclusive economic zone" (emphasis added). Despite this seemingly comprehensive catalogue of activities, Article 59 envisages activities where jurisdiction is not allocated and leaves it to be determined on a case by case basis ${ }^{24}$ :

\section{Basis for the resolution of conflicts regarding the attribution of rights and jurisdiction in the exclusive economic zone}

In cases where this Convention does not attribute rights or jurisdiction to the coastal State or to other States within the exclusive economic zone, and a conflict arises between the interests of the coastal State and any other State or States, the conflict should be resolved on the basis of equity and in the light of all the relevant

\footnotetext{
${ }^{24}$ It has been argued that this provision may be the basis for the "creeping jurisdiction" by coastal States: See: Niquole Esters, "Impacts of Language: Creeping Jurisdiction and its Challenges to the Equal Implementation of the Law of the Sea Convention", in Difficulties in Implementing the Provisions of UNCLOS, Conference paper for the 2008, HO/IAG Advisory Board on the Law of the Sea Conference. Online<http:www.gmat.unsw.edu. au/ablos/ABLOS08Folder/Session5-Paper1-Esters.pdf >.
} 
circumstances, taking into account the respective importance of the interests involved to the parties as well as to the international community as a whole. (emphasis added)

Finally, it must be recalled that within the potential 188 NM of an EEZ beyond the 12 NM Territorial Sea, there is also the possibility that a State can declare a "contiguous zone" of an additional $12 \mathrm{NM}$ beyond its Territorial Sea where it can apply certain national legislation. ${ }^{25}$ There are also a number of other provisions in the Convention involving regulatory rights and responsibilities in the EEZ in connection with Part XII, Protection and Preservation of the Marine Environment, and Part XIII, Marine Scientific Research.

For the purposes of this General Report, whether or not a State has ratified LOSC, the main point to take from this resume of the LOSC provisions is that coastal States have significant regulatory ambit in these areas if their legislation is tied to natural resource or other economic activities or protection and preservation of the marine environment subject to the specific freedoms or rights identified. While it was at one point, particularly before the 1982 LOSC entered into force, of some interest to question whether the law relating the EEZ was customary international law or debate the legal nature of the EEZ, given the number of countries that have ratified the $\mathrm{LOSC},{ }^{26}$ it is now clear that a spatial claim out to $200 \mathrm{NM}$, if geographically possible, is not contested. For the most part, the jurisdictional allocations

\footnotetext{
${ }^{25}$ LOSC, Article 33, Contiguous Zone, provides
}

1. In a zone contiguous to its territorial sea, described as the contiguous zone, the coastal State may exercise the control necessary to: (a) prevent infringement of its customs, fiscal, immigration or sanitary laws and regulations within its territory or territorial sea; (b) punish infringement of the above laws and regulations committed within its territory or territorial sea.

2. The contiguous zone may not extend beyond 24 nautical miles from the baselines from which the breadth of the territorial sea is measured.

${ }^{26}$ As of 20 September 2011,162 States are party to the LOSC, online: <http://www.un.org/dept/los reference_files/status2010. pdf $>$. Or, even if they have not ratified the Convention, they have adopted extended maritime claims either before its adoption or after 1982. As of 2010, on a very "rough count", 135 States, had claims for either a 200 NM EEZ or Exclusive Fisheries Zone or some other zone, or had extended claims delimited by agreement with other opposite or adjacent States. See: published summary table of claims in 31 July 2010, online: as set out in LOSC are generally observed (even if they are not yet customary international law). However, especially since the early 1990s, there have been challenges posed to these allocations by countries that, although party to the LOSC, have proposed extensions of jurisdiction, based on concepts such "mar presencial" 27 or "stewardship", ${ }^{28}$ to areas adjacent to the EEZ or have attempted to impose national laws in excess of international standards on foreign-flagged ships navigating in the EEZ. ${ }^{29}$

<http://www.un.org/Depts/los/LEGISLATIONANDTREATIES/ PDFFILES/table_summary_of_claims.pdf $>$.

As noted in the National Reports by Mag. Petra Ferk (Slovenia) and by Drs. Treves and Papanicolopulu (Italy) the countries bordering the Mediterranean have some difficulty in making such claims because of proximity; however, some States are claiming ecological protection or similarly named zones beyond the Territorial Sea, e.g., France, Solvenia, Italy. However, these countries have also adopted a regional convention-based regime, the Barcelona Convention (1976 Convention for the Protection of The Mediterranean Sea Against Pollution), a system to address environmental protection concerns. See Discussion in: Seminar on the legal aspects of the Barcelona Convention and its Protocols, online: <http://www.mepielan. gr/int-sem-02-en.html>.

${ }^{27}$ The concept of "mar presencial" (Presential sea) was initially proposed by Chile as a solution for the problem of straddling stocks. See: Christopher C. Joyner and Peter N. De Cola, "Chile's Presential Sea Proposal: Implications for Straddling Stocks and the International Law of Fisheries", in 24 Ocean Development \& International Law, 99 (1993); Thomas A. Clingan Jr., "Mar Presencial (the Presential sea): Deja Vu all over again? - A Response to Francisco Orrego Vicuna", in 24 Ocean Development \& International Law, 93 (1993).

${ }^{28} \mathrm{~A}$ concept that has been discussed in Canada, in connection with concerns about overfishing of the straddling stocks adjacent to Canada's EEZ in the Atlantic.

${ }^{29}$ For example. the European Directive, supra note 13. Or, as noted by Charlotte Briede and Phillip Saunders in "Challenges To The UNCLOS Regime: National Legislation Which Is Incompatible With International Law" (citations removed):

In another example of a coastal State regulation which may extend beyond the confines of MARPOL (and thus of UNCLOS), the Canadian government in 2005 responded to a perceived problem with seabird oiling caused by oily bilge water dumping by amending the Migratory Birds Convention Act (MBCA). The amended Act, which applies in the EEZ, makes it an offence for any person or vessel to "deposit a substance that is harmful to migratory birds, or permit such a substance to be deposited, in waters or an area frequented by migratory birds..." (see s. 5.1(1)). 
It is well known that increasingly wider areas of offshore jurisdiction, albeit on varying bases and using varying terminology (for example, territorial sea, exclusive fisheries zone), were already claimed by a number of States well before the development of the EEZ concept in the 1970s in connection with the negotiation of LOSC. In fact, coastal State claims over marine resources in areas of various breadth beyond the, then accepted, Territorial Sea in relation to coastal fisheries and the continental shelf were established in the 1940s. ${ }^{30}$ As noted by Churchill and Lowe, ${ }^{31}$ it is customary to regard the Proclamations by President Truman of the USA in 1945 as the first clear assertion of the idea that the continental shelf belongs to the coastal State on the basis that:

[T] he exercise of jurisdiction over the natural resources of the subsoil and sea bed of the continental shelf by the contiguous nation is reasonable and just, since the effectiveness of measures to utilize or conserve these resources would be contingent upon cooperation and protection from the shore, since the continental shelf may be regarded as an extension of the land-mass of the coastal nation and thus naturally appurtenant to it [].

This claim and its rationale (which came to be known as the "continental shelf doctrine") was followed in the

MARPOL-compliant discharges, such as permissible levels of oily bilge water, would be protected by a separate provision exempting "authorized" discharges under the Canada Shipping Act 2001, which applies MARPOL standards. However, the broad language of the prohibition, which would apply to substances other than oil, comes up against the requirement under UNCLOS that such measures must be made pursuant to an internationally accepted standard, and there is no indication of what international rule or standard this provision is implementing.

Conference paper for the 2008, HO/IAG Advisory Board on the Law of the Sea Conference: Difficulties In Implementing The Provisions Of UNCLOS, online <http:www.gmat.unsw. edu.au/ablos/ABLOS08Folder/Session5-Paper2-Briede.pdf $>$

${ }^{30} \mathrm{R}$. R. Churchill and A. V. Lowe, The Law of the Sea, 3rd ed. (Manchester: JURIS Publishing/Manchester University Press, 1999), 143. They note that there was an earlier treaty in 1942 , entered into by the United Kingdom on behalf of Trinidad, with respect to the Gulf of Paria: Great Britain - Venezuela, Treaty relating to the Submarine Areas of the Gulf of Paria, Caracas, 26 February 1942, 205 LNTS 121. President Truman of the United States issued two proclamations in 1945, Policy of the United States with Respect to the Natural Resources of the Subsoil and Sea Bed of the Continental Shelf and Policy of the United States with Respect to Coastal Fisheries in Certain Areas of the High Seas.

${ }^{31}$ Churchill \& Lowe, id. late 1940s with 200 NM claims regarding extended marine areas (then described as a "patrimonial sea") made in Proclamations and Declarations issued by Chile and Peru and others. ${ }^{32}$ The efforts to codify the law of the sea in 1958 with the Geneva Conventions adopted at UNCLOS I and later in 1982 in the LOSC at UNCLOS III, were, in part, the result of concerns about "creeping" coastal State jurisdiction and potential conflicts with States exercising traditional navigational and other rights in these areas. ${ }^{33}$

${ }^{32}$ Santiago Declaration 1952, and see also examples in Churchill \& Lowe, supra note 32 at 160 , note 2 . Oxman, supra note 14 comments at 831-32:

The mid-twentieth century was also a watershed for the international law of the sea, but of a very different sort. At the same time that the territorial temptation ran up against increasingly important legal constraints on land-often in response to the values of facilitation of trade, communication, and cooperation, which had traditionally informed the law of the sea-the obverse again occurred at sea. The territorial temptation thrust seaward with a speed and geographic scope that would be the envy of the most ambitious conquerors in human history. The effective start of this process-President Truman's claim to the continental shelf in 1945[] — was so quickly accepted and emulated by other coastal states []that the emergence of the regime of the continental shelf, in derogation of the principle of mare liberum, [ ] has been cited as an example of instant customary law.[ ] The Truman Proclamation unleashed a quarter-century of territorial and quasi-territorial claims to the high seas so vast that, at the dawn of the Third United Nations Conference on the Law of the Sea, the leader of the Canadian delegation, Ambassador J. Alan Beesley, could quip that he comes to bury Grotius, not to praise him.

${ }^{33}$ The adoption of the EEZ can also, perhaps, be viewed as an example of "creeping" coastal State jurisdiction or property rights claims challenging the management problems posed by freedom of the seas "commons"/high seas regime. Certainly the recognition of extended legal jurisdiction for coastal States must be understood as a necessary accompaniment to the technological developments that increasingly permit the use or occupation of ocean space and submerged lands for a variety of purposes (e.g., communications, resource development, and wind and tidal energy). At the same time, some of the traditional high seas navigational and other user rights and freedoms of other States (most notably "freedom of navigation") are also preserved in the EEZ that is described in LOSC. Recently, however, there have been attempts by coastal States to exercise greater control in this zone vis-à-vis maritime transport and other users, largely on the basis of a need to provide protection to coastal interests and resources. As explained by Eric Franckx in his interesting study ("The 200-Mile Limit: Between Creeping Jurisdiction and Creeping Common Heritage? - Some Law of the Sea Considerations from Professor Louis Sohn's Former 
As mentioned earlier, in the infancy of the development of the EEZ there was also some debate about whether its legal nature was really that of the high seas with some limitations on freedoms or the territorial sea with some incursions on sovereignty. This question was extensively analyzed by Kwiatkowska ${ }^{34}$ in her examination of the arguments for the residual High Sea character of the EEZ versus the sui generis character. The more contemporary view is, perhaps, best captured by Churchill and Lowe who argue that neither the residual High Sea character nor the Territorial Sea character was accepted. They suggest that: "[i]nstead, the EEZ must be regarded as a separate functional zone of sui generis character situated between the territorial and high sea." ${ }^{35}$ Of course this view still leaves open the question of the continental shelf which is claimed on what are, essentially, traditional notions of territory.

Thus under LOSC there appears to be two distinct legal bases for claims. The first is the "classical" continental shelf doctrine, which is set out in the 1958 Convention on the Continental Shelf, and retained in Part VI of LOSC, and the second is the modern basis for the EEZ in Part V of LOSC. The result is that under LOSC the maximum (EEZ)/minimum (CS) breadth is $200 \mathrm{NM}$, however the continental shelf exists ipso facto while the EEZ must be claimed. As noted in the oft cited judgment of Judge Oda (in dissent) in the 1982 Case concerning the Continental Shelf (Tunisia/ Libyan Arab Jamahiriya) ${ }^{36}$ :

120. It is widely recognized that the concept of the exclusive economic zone has become irresistible, and the way seems paved towards the institution of a régime for it

LL.M. Student", The George Washington International Law Review, 39(3) (2007): 467-98) of this phenomenon outside 200 NM (citation removed):

Creeping can be carried out either by the coastal State, in which case the widely used term "creeping jurisdiction" is normally relied upon, or by the international community, a process referred to by the term "creeping common heritage." Creeping jurisdiction can further be subdivided into creeping "qualitatively inside the 200-mile limit and spatially beyond that limit."

See concerns voiced by Oxman, supra note 14 .

${ }^{34}$ See Kwiatkowsa, supra note 14 at pages $230-235$.

${ }^{35}$ Churchill \& Lowe, supra note 30 at pp. $160-161$.

${ }^{36}$ ICJ Reports (1982) 222-34, paras. 108-130. Online at <http:// www.icj-cij.org/docket/index.php?p1=3\&p2=3\&code=1m\&cas $\mathrm{e}=68 \& \mathrm{k}=\mathrm{a} 8>$. under international law, incorporating a uniform limit of 200 miles. Throughout the history of international law, scarcely any other major concept has ever stood on the threshold of acceptance within such a short period. Even apart from the provisions of the 1981 draft convention, the Court need have few qualms in acknowledging the general concept of the exclusive economic zone as having entered the realm of customary international law. Yet I cannot but point out two problems in this respect: first, quite apart from the treaty-making process, the sui generis régime of the exclusive economic zone is going to require much more careful examination before the rules so far adumbrated may be viewed as susceptible of adoption into existing international law; secondly, the relation of the zone to the continental shelf remains profoundly ambiguous, particularly where such "interface" issues as the exploitation of ocean-floor minerals are concerned.

Despite the aspirations of the 1970s regarding a new international economic order ${ }^{37}$ and the potential wealth generated by the exercise of exclusive economic rights in this area, there has been relatively little development and use of these areas other than in connection with fisheries and offshore oil and gas exploitation. Even this has been problematic, with significant management failures on the part of coastal States and

${ }^{37}$ Churchill \& Lowe, supra note 30, explain that the concept of the EEZ, which eventually "effectively merged" with the South American concept of the "patrimonial sea", was first put forward at UNCLOS III by Kenya in 1971. They point out,

The EEZ is a reflection of the aspiration of the developing countries for economic development and their desire to gain greater control over the economic resources off their coasts, particularly fish stocks, which in many cases were largely exploited by the distant-water fleets of developed States.

The authors conclude (at page 179), however, that the establishment of the EEZ/EFZ led to some redistribution of fishery resources from distant-water fleet flag States to the coastal State and that with respect to resources other than fish, in the case of offshore oil and gas, "the introduction of the EEZ effected no redistribution.... Overall, therefore it is likely that the introduction of the EEZ concept has not produced as much material gain for the developing countries as its original proponents suggest." It should be noted that in 1999 the potential value of genetic resources or other mineral resources such polymetallic sulfides was not well developed; however, the conclusions are likely to remain much the same. I note the absence of National Reports from the countries most involved in the development of the EEZ concept is unfortunate. A similar problem and gap was identified at the 10th IACL Congress in 1978 by the General Reporter, Kenneth Simmonds (Great Britain), on the topic, "International Law and the New International Economic Order." 
increasing pressure to "globalize" regulation of fisheries in the EEZ through regional organizations. ${ }^{38}$

However, with growing demands for alternative forms of energy, particularly wind energy and other forms of marine renewable energy, and more research into more diverse resources and activities such as bioprospecting for genetic resources, there is now a need to provide for regulation and operation of these activities and also to support the commercial aspects of economic development, including, for example, matters such as property rights to secure credit for investors and employment law to govern the situation of workers.

There are some parallel trends that must also be considered. In 1992, a decade after the adoption of LOSC, the international community also began to adopt an ecosystemic world view and an integrated management based approach to addressing the relationship between human activities - particularly economic activities and the natural environment. In connection with ocean and resources, this has generated the development of integrated ocean action plans or strategies and/or policies together with a related legal framework to govern activities in these areas. These ocean governance policies also serve to align the institutions that regulate ocean and seabed uses, usually on a sectoral basis. The national policies have also evolved in different ways

\footnotetext{
${ }^{38}$ See the 1995 Agreement for the Implementation of the Provisions of the United Nations Convention on the Law of the Sea of 10 December 1982 Relating to the Conservation and Management of Straddling Fish Stocks and Highly Migratory Fish Stocks, online: <http://www.un.org//depts/los/convention agreements/texts/fish_stocks_agreement/CONF164_37.htm>, and the "compatibility principle":
}

\section{Article 7}

Compatibility of conservation and management measures

1. Without prejudice to the sovereign rights of coastal States for the purpose of exploring and exploiting, conserving and managing the living marine resources within areas under national jurisdiction as provided for in the Convention, and the right of all States for their nationals to engage in fishing on the high seas in accordance with the Convention...

2. Conservation and management measures established for the high seas and those adopted for areas under national jurisdiction shall be compatible in order to ensure conservation and management of the straddling fish stocks and highly migratory fish stocks in their entirety. To this end, coastal States and States fishing on the high seas have a duty to cooperate for the purpose of achieving compatible measures in respect of such stocks. In determining compatible conservation and management measures, States shall: ... (emphasis added) and reflect differing themes over time, for example, in some countries, "healthy oceans" is now a unifying theme. For example, a relatively recent project (2007) $)^{39}$ by the Intergovernmental Oceanographic Commission (IOC) of the United Nations Educational, Scientific and Cultural Organization (UNESCO) reflects the current interest in comparative studies of this new generation of approaches to ocean space governance.

\subsection{The National Reports: Illustrative Studies of the National Treatment of the EEZ and Continental Shelf}

As mentioned above, this General Report and the National Reports on which it is based, can do no more than provide a snapshot of the contemporary situation regarding the extent of a coastal State's legal occupation of these two areas, to the extent that they are distinguishable.

\subsubsection{General Information}

The questionnaire for this Session asked some basic background $^{40}$ questions relating to ratification of the LOSC and prior Conventions. Of the National Reports

\footnotetext{
${ }^{39}$ See: IOC Technical Series, 75. Law of the Sea Dossier 1: Intergovernmental Oceanographic Commission. National Ocean Policy. The Basic Texts from: Australia, Brazil, Canada, China, Colombia, Japan, Norway, Portugal, Russian Federation, United States of America (Paris, UNESCO, 2007). Online: <http://ioc3. unesco.org/abelos/index.php?option=com_content\&task=view $\& \mathrm{id}=55 \&$ Itemid $=62>$. This study comprises a collection of national ocean policies, including the legislation, much of which establishes the legal framework for the EEZ or similar zones underpinning these policies.

${ }^{40}$ Specific questions to consider in relation to national legislation, case law or other policies and practices:
}

General/Descriptive

1. Is your country a party to the 1982 United Nations Convention on the Law of the Sea?

2. Is or was your country party to the 1958 Convention on the Continental Shelf?

3. Did your country adopt legislation to implement the 1958 Convention (if a party)? Was this legislation amended after 1982 ?

4. Has your country adopted national legislation with respect to its maritime boundaries? 
received, three States ${ }^{41}$ are not party to the 1982 LOSC, but do claim an extended jurisdictional zone out to 200 NM. The point of interest was whether all States claimed areas beyond the Territorial Sea and, if so, what name was used and what form did national law take to cover this area. ${ }^{42}$ In line with the point mentioned above regarding ocean polices, the specific interest was whether an "Oceans Act" or some other form of unifying legislation or policy had been adopted and/ or whether there was spatial management policy or law in this area. The National Reports indicate that some countries ${ }^{43}$ have adopted an integrating "Oceans Act." Drs. Kozuka and Nakamura note with respect to Japan:

... a substantial shift in the Japanese law more than a decade after the ratification of LOSC. The Basic Act on Ocean Policy ..., enacted in 2007, acknowledged the importance of becoming "a new ocean-oriented nation striving for harmony between the peaceful and positive development and exploitation of the oceans and the conservation of the marine environment."

5. How wide is the territorial sea? If jurisdiction over any area of water or seabed beyond the territorial sea is claimed, what is the name and size of that area and what is the nature of the claim?

6. Has your country claimed an extended continental shelf? If so, what national legislation relates to that claim?

${ }^{41}$ Peru, USA, Venezuela.

${ }^{42}$ For example as noted earlier, supra note 26, Drs. Treves and Papanicolopulu, National Reporters for Italy, point out that in 2006 Italy adopted "ecological protection zones":

In 2006, Italy passed framework legislation for the creation of "ecological protection zones", to be established by Presidential Decree, wherein it will exercise part of the rights attributed to the coastal State by international law of the sea within its exclusive economic zone." No ecological protection zone has yet been established on the basis of this law. The reason seems to be the wish of Italy to negotiate the external boundaries of these areas before formally establishing them. It may be noted that Italian legislation refers to "zones" in the plural. However, these zones should not be confused with marine protected areas: the former are in fact maritime zones which can be established along portions of the entire coastline, while the latter are specific areas protected because of their special biological characteristics. The use of the plural is probably due to the intention of Italy not to establish an entire zone at once, but to begin along those coasts where environmental threats require urgent action. It is expected that the first ecological protection zone, encompassing the northern Tyrrhenian Sea, will be established during 2010.

See also National Report for Slovenia by Mag. Ferk, supra note 28 .

${ }^{43}$ In addition to Japan, Canada and the USA have enacted "Oceans" Acts.
However, many do not follow this approach although a number of countries in Europe, largely as a result of EU regionalism, have adopted marine spatial planning approaches. ${ }^{44}$ Although not in the EU, it is notable that Norway is gradually adopting a spatial planning approach. ${ }^{45}$

Others noted significant fragmentation and sectoral management and legislation, despite efforts at integration. ${ }^{46}$ In her report on the USA Professor Salcido explains that:

The United States has a multitude of overlapping and untidy laws "on the books" applicable to the EEZ. It has leadership capacity, and it has the public's interest in the resources in mind. To date, however, these elements have failed to yield an effective legal framework for ocean management.

Similarly Professor Dragun-Gertner, Dr. Pyć and Zuzanna Peplowska note in their report on Poland that:

Applicable national legislation is partially specific for maritime activities and partially of a general nature. A dual approach to maritime areas management of Poland consists of both the sectoral approach (e.g., fishing, shipping, marine spatial planning) and the integrated approach

${ }^{44}$ As noted by Drs. Maes and Somers in their National Report for Belgium:

The legislative framework in Belgium has shaped marine spatial planning (MSP) into a continuous process.

See also the Reports from the other EU countries.

${ }^{45}$ Dr. Henriksen (Norway) explains that

There is a gradual spatial approach in newer legislation pertaining to the maritime areas.

The 2009 Nature Management Act, aimed at preserving diversity of biology, landscapes, and geology, is also applicable to the maritime zones of Norway. The Act includes more specific objectives to protect the diversity of habitats and ecosystems, and is applicable across sectoral legislation. It reflects the ecosystem approach, requiring a more spatial approach in the management of natural resources and the environment. One of the measures under the Act is marine protected areas (MPAs). This measure is not applicable to the EEZ or the continental shelf as measures adopted under MPAs arguably may impede on the rights of other states under the law of the sea. The Planning Act has recently been amended to be made applicable in maritime areas (one nautical mile from the baselines), including internal waters and a minor part of the territorial sea. Spatial planning and a more holistic approach to management in the maritime areas are mainly regulated through government policy. The ecosystem-based approach is a central element in Norwegian ocean's policy ....

${ }^{46}$ See the National Report for Japan. 
(e.g., environmental protection, nature conservation, general principles of coastal and marine spatial planning, as well as construction permits). The problem with the good practice of managing space of the marine environment is that it is done on a single-sector basis, mainly without a plan-based approach and with little or no consideration of objectives from other conflicting uses or conservation requirements. The lack of an integrated approach that pays attention to the heterogenic characteristics of marine space leads to conflicts among users, and between human uses and the natural environment.

In general, boundary making and continental shelf claims especially where extended claims might exist was reported as a preoccupation ${ }^{47}$ even for countries that have not ratified the LOSC. ${ }^{48}$ As noted by Dr. Jaffé in connection with Venezuela:

\begin{abstract}
Venezuela was an active participant in the development and creation of the 1982 United Nations Convention of the Law of the Sea (UNCLOS). However, as article 309 explicitly forbids the possibility of making reservations to any article or part of the Convention, Venezuela was one of the four States that voted against it.

Venezuela's main objections concern article 15, which refers to the delimitation of territorial waters; article 121, which establishes distinctions between different categories of islands; and the part referring to the creation of the International Tribunal on the Law of the Sea. The underlying concern is a pending delimitation problem with the Republic of Colombia in the Gulf of Venezuela.
\end{abstract}

However, as Dr. Roy (Canada) explains, Canada is one of the relatively few countries that will be able to claim a continental shelf extending beyond $200 \mathrm{NM}$.

\subsubsection{National Law and Practice}

The purpose of this section of the General Report is not to reproduce or even attempt to summarize the National Reports, many ${ }^{49}$ of which are published elsewhere, but rather to highlight some points that are of special interest. The questionnaire for this Session asked whether legislation had been adopted with respect to specific resource management and regulation in these areas and related jurisdictional questions, as well as inviting observations and reflections by the

\footnotetext{
${ }^{47}$ See e.g., Dr. Roy, (Canada); Dr. Henriksen (Norway).

${ }^{48}$ See the National Reports for the USA and Venezuela.

${ }^{49}$ See inter alia: Ocean Yearbook, Vol. 25, eds. S. Coffen-Smout, A. Chircop, M. L. McConnell (Leiden: Brill, 2011)
}

National Reporters. ${ }^{50}$ One point that appears common is that the EEZ and the continental shelf, irrespective of the continental shelf doctrine, is not ${ }^{51}$ regarded as "territory" and requires an express extension to also apply national public law in areas beyond the Territorial Sea. ${ }^{52}$ For example, as explained by Dr. Wurmnest (Germany) regarding the situation in Germany:

Therefore the legislature must (directly or implicitly) state in each law it passes in the realm of public law,

\section{${ }^{50}$ Sectoral Resource Management}

7. Has legislation been adopted with respect to specific resource management and regulation? More specifically has it been adopted or changed with respect to

- energy (wind or other sources of ocean energy)

- mineral resources

- genetic resources

- fisheries

- aquaculture

- maritime transport

- communication

- scientific research

8. How are investment and the need for financial security(ies) addressed? How, if at all, has the private sector addressed this issue (contracts? loans/credit?) Has there been any case law in connection with investments?

9. How is the area as a "work space" (labor/employment law) regulated? How is it addressed, if it is, in private sector employment relationships e.g., contracts, collective bargaining arrangements?

10. Has any preventative action taken place, e.g., creation of marine protected areas? If so, was this in connection with the LOSC or MARPOL?

Enforcement of Jurisdiction

11. Does your country enforce legislation/rights in these areas and, if so, how does it do so?

12. Are national courts given jurisdiction in these areas? If so, in what form is this granted? Has it ever been exercised?

13. What institutions or agencies are responsible for enforcement of jurisdiction in these areas?

\section{Reflection}

Please include a brief reflection on what you perceive to be the interests of your country and private sector actors in connection with this topic and what you see as the main issues in the future.

${ }^{51}$ But see: Dr. Luís de Lima Pinheiro (Portugal) where this does not appear to be the case.

${ }^{52}$ See Dr. Wurmnest (Germany) Although not specifically addressed in Dr. Roy's National Report for Canada, it is noted that the Oceans Act" (1996, S.C., c.31) adopts an approach to addressing this issue by generally extending legislative and court jurisdiction to the EEZ and continental shelf " ... as if the places referred to ... formed part of the territory of Canada....." (e.g., s.20 (2) s.21 (31)). 
whether this law (or parts of it) shall cover activities on the German continental shelf or in the EEZ claimed by Germany. As matters relating to the EEZ and the continental shelf are often seen as "side issues" of legislation relating to specific fields, for example legislation covering environmental protection or spatial planning, the Federation has not enacted a comprehensive "maritime code", but has passed or amended various (public law) statutes and regulations in order to cover activities in the waters beyond Germany's territorial sea. (notes removed)

A similar conclusion and doubt as to the application of legislation adopted by the Netherlands was expressed by Dr. Verwer who points out that:

The Water Management Act essentially went into effect on 1 January 1997. Its purpose is to protect waterworks owned by the Kingdom of the Netherlands against damage of any kind and to promote an efficient and safe use of these waterworks. Although the intention is clearly to make the Water Management Act applicable to the EEZ, (regulated by Act of November 15, 2000 which went into effect on 6 December 2000) one might conclude the method to achieve this result is not effective. In article 1 , paragraph 2, the definition of waterworks has been extended to the EEZ as well. This deserves critical consideration; I propose that applicability beyond the boundaries of the territorial waters can only exist by means of an explicit article in the Act stating its applicability. Here the only mention is of extension of a definition to cover the EEZ as well, which is quite different from the explicit statement of applicability outside of the territorial waters. The Act's explicit statement that it is not applicable to extractive activities in the EEZ, leading to the contrary rationale that the Act is applicable to the EEZ regarding all other aspects, does not convince me. This exemption of applicability to the EEZ is caused by the fact that the Extraction Act has its own system for licensing and supervision by authorities. (emphasis added)

In that context it is interesting to note that Dr. Verwer (The Netherlands) points out, by contrast, in connection with (presumably) Dutch workers on the EEZ:

Apart from the applicability of the acts and regulations presented above, I would like to draw attention to certain other aspects in Dutch legislation applicable in the EEZ. Article 2, paragraph 3 of the Industrial Disability Insurance Order (Besluit uitbreiding en beperking kring verzekerden WAZ) states that workers in the EEZ are not considered to be working abroad. Therefore they have the full benefit of the national social security system as far as disability insurance is concerned. This means that a part of the Dutch social security system has extraterritorial applicability. This is not the only example. Article 12, paragraph 3 of the Extension and Limitation Circle Insured People National Insurance Order 1999 (Besluit uitbreiding en beperking verzekerden volksverzekeringen 1999) contains the same extension concerning national insurance in favor of workers in the EEZ (notes removed, emphasis added).

Other countries such as Belgium have adopted legislation explicitly directed to the EEZ and/or the continental shelf. Drs. Maes and Somers (Belgium) explain:

The focus of the 1999 EEZ Act is on exercising sovereign rights for the purpose of exploring and exploiting natural resources, as well as conservation, protection, and management of these living and non-living natural resources, whether on the subsoil, the seabed, or in superjacent waters. The Act enables further legislation regarding other economic activities, such as production of energy from the water, currents, and winds (see supra offshore wind energy) (article 4).

The majority of the National Reports are concerned with what may be regarded as the application of reasonably well developed (even if fragmented) public law. Most did not address the private law aspects in great detail. However Dr. Wurmnest in his report on Germany provides a thoughtful and lengthy exposition of potential private law questions in the context of both the application of general principles on the conflict of laws and the application of EU treaty law on the conflict of laws:

Thus far, this report has highlighted public law provisions applicable to the EEZ and the continental shelf. The increased number and intensity of activities taking place outside territorial waters have also generated a variety of legal problems falling in the realm of private law. German private law applies to offshore activities on the continental shelf or in the German EEZ if envisaged by the rules of private international law. For certain areas of law, most notably contract and tort law, these rules were recently "communitarized" by enacting the so called Rome I and Rome II Regulations. Other matters are still governed by the German conflict rules laid down in the Introductory Act to the Civil Code (EGBGB). None of the aforementioned statutes comprises a special conflict rule for activities on the continental shelf or in the EEZ. Therefore existing general rules must be adapted to fit into the maritime context. Due to space constraints, the following overview is limited to three examples of private disputes: ship collisions, selected labor law disputes arising from employment contracts that are performed in the EEZ, and property rights related to objects located on the continental shelf or in the EEZ. 
Similarly, also in the EU context, Dr. Luís de Lima Pinheiro, ${ }^{53}$ in the National Report for Portugal, considers questions of private law but focuses more on the question of which court would have jurisdiction, describing the situation as follows:

Regarding jurisdiction for private law claims, the jurisdiction rules in tort matters shall be taken into account. In tort matters, the rules of the Brussels I Regulation (EC Regulation no 44/2001) are applicable where the defendant is domiciled in a Member State (Article 4(1)). A person domiciled in a Member State may be sued in the courts of that Member State (Article 2(1)) and in the courts of the place where the harmful event occurred or may occur (Article 5(3)). For this purpose the exclusive economic zone and the continental shelf are parts of the coastal state. The Brussels I Regulation does not affect the conventions to which the Member States are parties and which, in relation to particular matters, govern jurisdiction (Article 71(1))..... Outside the scope of application of the Brussels I Regulation and of the aforementioned Brussels Convention, the jurisdiction in tort matters is defined by internal rules. The general jurisdiction rule is contained in Article 65 of the Code of Civil Procedure. Article 65(1)(b) refers to the rules of territorial jurisdiction. According to these rules, the court of the place where the harmful event occurred has jurisdiction in tort matters (Article 74(2))..... Article 65(1)(c) allows the jurisdiction of the Portuguese courts where any of the facts that form the cause of action occurs in Portuguese territory. This paragraph has been abrogated by the Lei no 52/2008, of 28 August, but it is doubtful whether this abrogation has any effect before 1 September 2010 (Article 187 of the referred Lei). It seems sustainable that for the purpose of all these internal jurisdiction rules

\footnotetext{
${ }^{53}$ In his comments to the Session at the XVIIIth Congress, Dr Pinheiro made proposals, essentially agreeing with points made by Dr Wurmnest, on the question of which law would likely apply, at least in the EU context (Rome Treaty). In his view it was important to try to present some suggestions as to the likely application of law in order to help provide certainty. He provided suggestions with respect to contract, tort and property claims. In his opinion the following could be seen as likely scenarios:

1. Contracts: The choice of law under the contract would prevail followed by location of the object (if a contract regarding an immovable) and if a contract is for employment then it would be the place where the work is located subject to the overriding provisions regarding the law most favorable to protect the workers.

2. With respect to torts it is likely to be the general principle of "where the damage occurs." However, in the case of "internal torts" on ships, that would be the law of the flag state, while in the case of "external torts" it would be the coastal state.

3. In connection with property claims it would be the most recognizable law and distinctions might be drawn between, for example, chattels on rigs and other claims.
}

the exclusive economic zone and the continental shelf may be considered part of the Portuguese territory. The reporter has no notice that this jurisdiction has been exercised.

Questions of property law are, however, more complex. As Professor Salcido (USA), also points out, there is, increasingly, an interest, even an "agitation" as she describes it, in the USA, regarding the lack of developed property law for the EEZ and continental shelf and the problems posed by these demands in the context of what is seen as public resources:

\section{B. Agitation for Property Rights in the OCS and EEZ}

As the previous sections have indicated, new developments on the OCS [outer continental shelf] and in the EEZ have required assessing existing legal tools. Among the multiple policy prescriptions suggested, many call for increased reliance on property rights. Yet concern about awarding exclusive rights to public resources, even within a limited time frame, accompanies all new authorizations of EEZ and OCS uses.

By proclaiming a 200-mile EEZ, the United States does not claim exclusive ownership of the seabed and subsoil or of the water column above. While it has not been tested, the issue of property rights on the OCS and in the EEZ is unclear and only recently is being explored by scholars. Gail Osherenko puts it thus:

[T] he 1982 Convention does not clarify whether the extension of sovereign rights over the EEZ includes property rights ... Commentators and scholars have expounded at length on the extension of authority under the 1982 Convention, as well as the constraints on coastal state authority. But they have not explored the nature of property rights, if any, that coastal states may claim as a result of declaring an EEZ.

.

The question of property rights is pertinent today because investors in EEZ development have agitated for maximum financial security. In general, the federal government has provided security to investors in OCS and EEZ developments through permits, leases, easements, licenses, and right-of-ways. OCSLA property rights have been the subject of interpretation in U.S. courts, exposing the limited nature of the rights conveyed by OCSLA leases. A lease under OCSLA does not convey title. Nonetheless, it is a vested property interest which allows one granted such interest recourse to the government to stand behind an assertion of the rights granted.

U.S. courts also seek to address issues of security regarding offshore development by contract law, or by alternative legal analyses such as application of the Sovereign Acts Doctrine or the Unmistakably Doctrine. For example, an agency must compensate for a breach of 
its regulatory contract even if the breach is compelled by an act of Congress. In Mobil Oil Exploration \& Producing Southeast, Inc. v. United States, the Supreme Court granted restitution to plaintiffs whose oil and gas "lease contracts" were breached by delay and subsequent revision of the process for approving exploration and production plans and obtaining drilling permits.

Thus, there are a variety of ways to ensure reliability and security of tenure for offshore developers vis-à-vis the U.S. government which has not required resolution of the exact nature, if any, of the property rights of the United States in the EEZ. Remedies arising from contract law and other principles of restitution serve as security for investors. Yet each step taken toward increasing security in offshore developments is accompanied by criticism regarding the abdication of government responsibilities toward quintessentially public resources. In the following section this critique is evaluated through discussion of a public trust in EEZ resources.

In connection with use of contractual arrangements for projects located in the EEZ it is of interest to note the situation in Poland that is described by Professor Dragun-Gertner, Dr. Pyć and Zuzanna Peplowaka in their National Report:

The Contract for Use is in fact a lease contract. By definition, all Polish sea areas within the territorial sea and internal sea waters are the property of the State and cannot be sold, therefore the lease is given for a limited period. The contract contains the amount of the annual rent, the calculation of which is defined by law. Stipulations of the Erecting and Use Permit are an integral part of the Contract. Of course the Contract cannot be drawn for sea areas located in the EEZ, since by international law, though their use is controlled by the coastal State, they are not a part of its territory.

\subsection{Observations and Conclusions}

The foregoing discussion has highlighted some points of interest with respect to "the law applicable on the continental shelf and in the EEZ". The following observations can be made:

- Despite the codification and development of the international regime, the "applicable law" still remains uncertain, fragmented and in general undeveloped or certainly misunderstood, particularly with respect to application of private law.

- At the same time, the EEZ and continental shelf are clearly not "law free zones."

- Regionalism is having a significant impact on the law applicable in these areas, and also creating additional uncertainty even while seeking to create a further level of harmonization in approach among countries that are part of the European Union. The situation is complex in these countries with the various allocations of competencies in these areas.

- The law is also more complex in countries where there is a division of legislative jurisdiction between levels of governments in a State (for example, in federations).

- Significant attention has been paid to domestic law (which in turn reflects regional pressures) in connection with regulation of living resources (i.e., fish) in the EEZ and to spatial claims, especially in connection with establishing the outer limits of the continental shelf if it extends beyond the EEZ or is contested, even for states that are not party to the LOSC.

- Although the terminology differs, States have advocated and pursued various spatial planning efforts to develop integrated management and ocean policy conceptual approaches. However, in many cases, the law remains sectoral in focus.

- Relatively little attention has been paid to private law questions. There are clearly some problems and uncertainty in connection with, for example, mobile offshore drilling rigs, in connection with the question of the applicability of, for example, labor standards or jurisdiction to hear cases in the event of an incident or determining the applicable law.

The proposition can be advanced that the applicable law on the continental shelf and in the EEZ will probably be the law of the proximate coastal State (subject to internal or regional division of authority) except for the specific exceptions under the LOSC and other international law pertaining to flag state responsibility for events on board ships and aircraft when navigating through or flying over these areas. However, the extent to which national law does apply is not certain unless the State has expressly extended its law to apply outside its territory to these areas. The question of the application of private law in these two areas appears more complex and, as yet, relatively undeveloped. However, it is likely that the general principles of private international law that would apply in the case of conflict of law for contracts, torts and property law (for chattels) would be equally applicable, with the EEZ and continental shelf being considered as the territory of the relevant coastal State for this purpose. 